\title{
NOTES
}

\section{ANOTHER WHITMAN PHOTOGRAPH: THE GURNEY AND ROCKWOOD SESSIONS RECONSIDERED}

The William Bayley Collection at Ohio Wesleyan University holds an image that was overlooked in the Walt Whitman Quarterly Review gathering of the known Whitman photographs (vol. 4, Fall/Winter 1986-1987), nor has it been published elsewhere before this. The carte de visite is very similar to two others that $W W Q R$ did print, and the fact that Bayley had marked this one (incorrectly) and a print of WWQR 1870s-\#18 (correctly) as "S[aunders] \#40" on the reverse may have occasioned the error. These two are readily distinguishable by Whitman's wider eyes, his more erect posture, and the visibility of his white shirt beneath the tie in $W W Q R$ 1870s-\#18. Ironically, the image more closely resembles another print which Bayley owned and correctly marked as "S \#41" (WWQR 1870s-\#20). The differences between them are subtle: Whitman's posture is slightly more relaxed in the unpublished image (WWQR 1870s-\#20a), and, most tellingly, the folds in his sleeves indicate that his arm is not across his chest in \#20a as it is in \#20.

Clearly these three, WWQR numbers 18,20 , and 20a, are poses from the same sitting: even stray hairs and the knot in his tie are identical. WWQR 1870 s - \#19 seems a very close match, too, the only differences being that the face is lit from the opposite side and his hair still shows the telltale impression of a hat (which may mean that this is the first shot of the session). Whitman is again wearing the same black coat, white striped shirt, and Windsor tie in $W W Q R$ numbers 1870 s $-15,16$, and 17 , and, although it is more difficult to be absolutely certain because he is facing the opposite way, the particular disarray of the hair and beard seem to be very much like that of numbers 18-20a. The various dates that have been assigned to these seven portraits should not be taken as strong evidence of multiple sittings, since Whitman, Traubel, and later scholars were demonstrably inaccurate in such dating. As Ed Folsom points out, for example, Whitman dated \#18 variously as 1871 and 1872 , and Traubel dated \#19 as during the Civil War and \#15 as $1865 .{ }^{1}$ Moreover, \#20a is dated in what appears to be an unsteady version of Whitman's hand (as though he were holding it in one hand while signing it with the other) with the inscription "Walt Whitman 1864." From the poet's apparent age in this series, however, his usual estimate of 1871 or 72 is certainly more accurate.

Thus, all seven poses are likely from one sitting. But, strangely, all are attributed to Jeremiah Gurney and Son except for \#20, which is attributed to George G. Rockwood, in Saunders and on both Bayley's print and that held by the University of Virginia and printed in $W W Q R$. Since the appearance of the $W W Q R$ photography issue, however, a print of \#20 bearing the Gurney insignia has been made known, as well as a print of \#15 (generally ascribed to Gurney) bearing the Rockwood insignia. ${ }^{2}$ This all suggests that Whitman never 

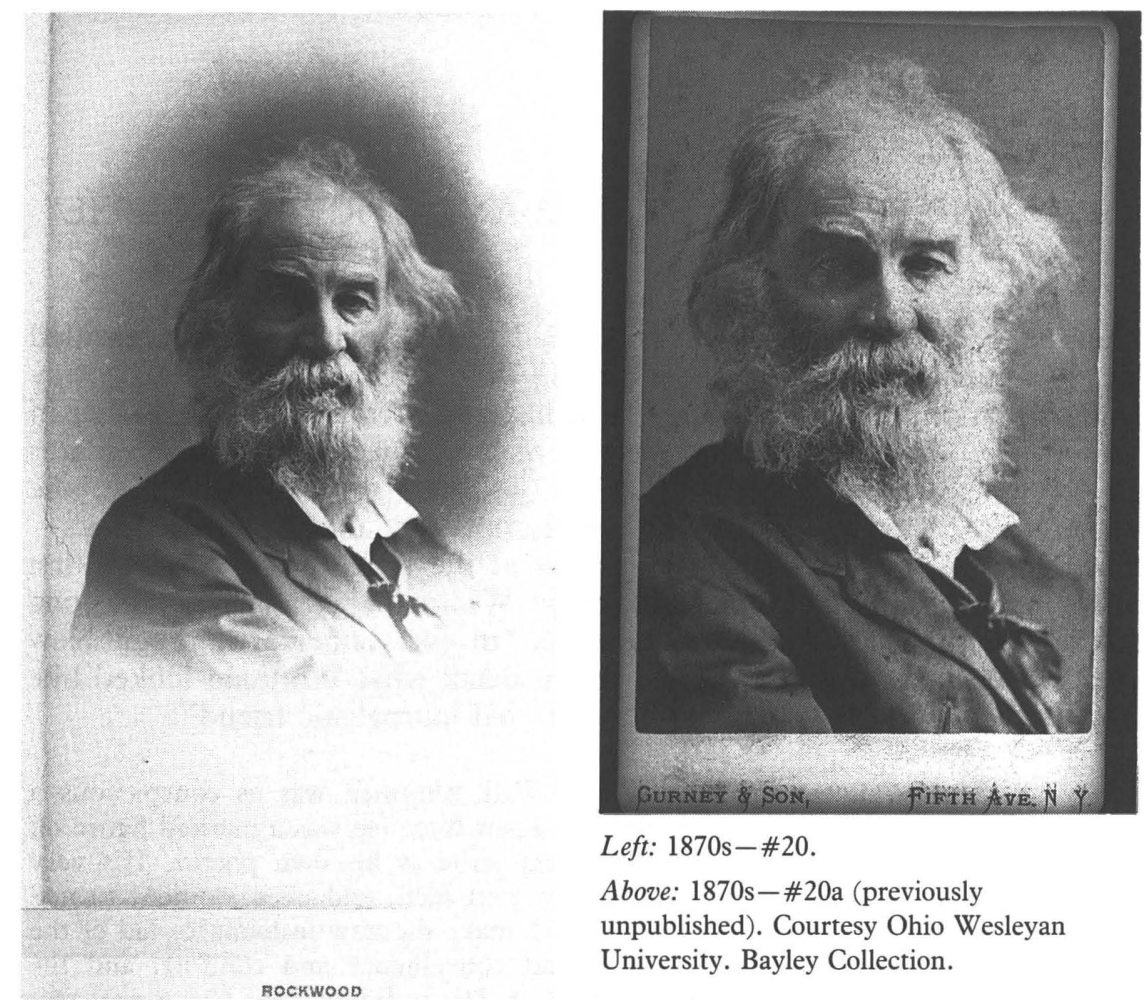

Left: 1870 s-\#20.

Above: 1870 s-\#20a (previously

unpublished). Courtesy Ohio Wesleyan University. Bayley Collection.

sat for Rockwood (the poet never mentions him, whereas he does mention dealings with Gurney several times, even sending Benjamin Gurney copies of his books). Rather, Rockwood's studio made prints after acquiring the negatives for this session, either through Whitman himself or through purchasing them from Gurney (which seems more likely, as photographers then, as now, normally retained negatives from studio portraits). As Whitman himself once told Traubel, the printing and distribution of his portraits had got somewhat out of hand as studios cashed in on his growing celebrity by selling prints from their Whitman negatives to the public: "my head gets about: is easily recognized. . . . I meet new Walt Whitmans every day. There are dozens of me afloat. I don't know which Walt Whitman I am.",3

The University of Michigan

JOHN RIETZ

\section{NOTES}

1 “Notes on Photographs," Walt Whitman Quarterly Review 4 (Fall/Winter 1986-1987), 50-51.

2 These prints are in the collection of Carl Mautz (Brownsville, California), confirmed in a letter to Ed Folsom, June 1, 1987.

3 Horace Traubel, With Walt Whitman in Camden, vol. 1 (Boston: Small Maynard, 1906), 108. 